Int. J. Electrochem. Sci., 15 (2020) $350-360$

International Journal of

ELECTROCHEMICAL

SCIENCE

$\underline{\text { www.electrochemsci.org }}$

\title{
Improved Photoelectrochemical Glucose Oxidation on Graphene Supported CdS Nanoparticles via Decoration of $\mathrm{CuO}$ Nanoparticles
}

\author{
Guoyan Zhao, Sujuan $\mathrm{Li}^{*}$ \\ Henan Province Key Laboratory of New Optoelectronic Functional Materials, College of Chemistry \\ and Chemical Engineering, Anyang Normal University, Anyang, 455000, Henan, China \\ *E-mail: lemontree88@163.com
}

doi: $10.20964 / 2020.01 .37$

Received: 4 September 2019 / Accepted: 19 October 2019 / Published: 30 November 2019

In this work, visible light driven photoelectrochemical glucose sensor was developed by electrochemically deposited $\mathrm{CuO}$ nanoparticles ( $\mathrm{CuO} \mathrm{NPs}$ ) on graphene (GP)-CdS nanocomposites modified electrode to achieve both the electrocatalytic and photoelectrocatalytic oxidation of glucose. Scanning electron microscopy, electrochemical impedance spectroscopy and cyclic voltammetry were used to characterize the morphology and electrochemical properties of the resultant $\mathrm{CuO}$ NPs/GP-CdS nanocomposites. The $\mathrm{CV}$ results demonstrated that modification of $\mathrm{CuO}$ NPs largely enhanced the photoelectrocatalytic activity of GP-CdS composites toward glucose oxidation in alkaline solution. The glucose detection sensitivity under visible light irradiation is dramatically improved compared to dark condition. Good performance was obtained for the $\mathrm{CuO}$ NPs/GP-CdS nanocomposites based glucose sensor. The feasibility of the present method was confirmed by good recovery results for glucose detection in human serum samples.

Keywords: Graphene; CdS, CuO nanoparticles, Glucose, Photoelectrochemical sensor.

\section{$\underline{\text { FULL TEXT }}$}

(C) 2020 The Authors. Published by ESG (www.electrochemsci.org). This article is an open access article distributed under the terms and conditions of the Creative Commons Attribution license (http://creativecommons.org/licenses/by/4.0/). 